\title{
How open is open access research in Library and Information Science?
}

\author{
Wanyenda Leonard Chilimo ${ }^{1}$ and Omwoyo Bosire Onyancha ${ }^{2}$ \\ wanyenda@gmail.com ORCID: orcid.org/0000-0001-8057-7405 \\ onyanob@unisa.ac.za ORCID: orcid.org/0000-0002-9232-4939
}

\begin{abstract}
Received: 26 November 2017
Accepted: 23 June 2018

The study investigates Library and Information Science (LIS) journals that published research articles between 2003 and 2013, which were about open access (OA) and were indexed in LIS databases. The purpose was to investigate the journals' $O A$ policies, ascertain the degree to which these policies facilitate $O A$ to publications, and investigate whether such texts are also available as $O A$. The results show that literature growth in the domain has been significant, with a total of 1,402 articles produced during the eleven years under study. The OA policies of the fifty-six journals that published the highest number of articles were analysed. The results show that most articles $(404 ; 41 \%)$ were published in hybrid journals, whereas 272 (29.7\%) appeared in OA journals. Some 143 (53\%) of the articles published in hybrid journals were available as green OA copies. In total, 602 (66\%) of all the articles published were available as $O A$. The results show that the adoption of OA for research articles on that very subject is somewhat higher than in other fields. The study calls on LIS professionals to be conversant with the OA policies of the various journals that may publish their research.
\end{abstract}

Keywords: LIS journals, open access, self-archiving

\section{Introduction and background information}

Open access $(O A)$ is an initiative that advocates for free, online access to scientific literature. It is a highly topical issue in both Library and Information Science (LIS) and the scholarly community at large. Research on the concept of OA has been on the rise as LIS scholars and researchers from other fields of study engage in research activities on various aspects related to the topic.

LIS scholars and practitioners have been at the forefront of promoting OA, but previous studies show that the adoption of OA as a method of publication in LIS-related academic works (and research in general) has not been as high as expected (Bowley and Vandegrift 2014, Mercer 2011, Way 2010, Xia, Wilhoite \& Myers 2011). The majority of studies investigated the general adoption of OA by LIS scholars and practitioners. This study narrowed down the investigation to an analysis of research articles on OA and the LIS journals that publish related research. Further, the authors set out to analyse the literature dealing with $O A$ and the characteristics of those journals that publish related research.

Within the framework of journal-driven OA ('gold' OA) and author-driven OA ('green' OA, also known as 'selfarchiving') (Laakso and Björk 2012), journals have adopted various strategies to ensure the free availability of scientific literature on the internet. Some of the strategies which journals have adopted are more open than others, hence the question: "How open is a specific journal?" (SPARC 2013).

With regard to gold OA, some journals make the electronic versions of their articles freely available, either directly (as in the case of $O A$ journals) or after a delay, typically of one year - a strategy commonly referred to as 'delayed OA' (Laakso and Björk 2012, Lin 2006, Mizera 2013). The majority of mainstream journal publishers have adopted a hybrid model of OA, which allows authors or their sponsors to access their articles for free from day one, against a payment (APS 2007, Björk 2012). Concerning green OA, some journals have conditions that prescribe what version of a publication its authors are permitted to self-archive, when that is permitted, as well as the location where self-archiving is allowed (Laakso 2014). The effectiveness of green OA and the likelihood of finding green copies of publications published in journals that allow self-archiving depend on how well researchers understand these policies and utilise their rights to self-archive, as permitted by the publishers.

1. Wanyenda Leonard Chilimo is University Librarian, Technical University of Mombasa, Kenya, and Research Fellow, Department of Information Science, University of South Africa

2. Omwoyo Bosire Onyancha is Research Professor in the Department of Information Science, University of South Africa 
The purpose of this study, therefore, was to investigate the LIS journals that publish OA-related research, in order to ascertain the degree to which 'green' and 'gold' OA policies respectively (as adopted by the journals) provide free access to research articles on the topic of OA. The study investigated whether research articles focusing on OA are published in $\mathrm{OA}$ journals, and whether they are available free of charge. We believe that this analysis will make it possible to predict the extent to which literature on the topic of OA will also be available as OA.

\section{Journal-level open access policies}

Stakeholders in the scholarly publishing community have responded to the call to open up access to scientific literature by instituting polices to promote the wide use and adoption of OA. Their response has led to the implementation of OA policies at various levels: at the institutional level, academic institutions around the world have developed OA policies (Poynder 2012, ROARMAP 2014, Xia 2012); at the funders' level, these policies have been adopted by donors and research funding organisations (Tonta, Doğan and Madran 2015); and at the journal level, OA-related policies offer access to articles published in different journals. Included here are publisher-permitted self-archiving policies which allow authors to keep a copy of their publication in the institutional repository, or any other location on the web. Few studies have been carried out to investigate journal-level OA policies. As Laakso (2014) pointed out, an under-explored area of research is the degree to which scholarly journal articles published in subscription-based journals could become OA through publisher-permitted uploading to freely accessible web locations.

A study by Bowley and Vandegrift (2014) proposed a new metric to rank journals, called the Journal Openness Index (JOI) factor. This index is based on measures of openness with regards to copyright, reuse rights, author posting rights, reader rights and automatic posting. The authors of the current article utilised the OA spectrum proposed by SPARC (2013) to analyse 111 LIS journals. A study by Laakso (2014), which investigated the green OA policies of 100 of the largest publishers extracted from the Scopus bibliographic database, reported that $80.4 \%$ of the 1.1 million articles included in the analysis could be uploaded to an institutional or subject repository one year after publication, either as an accepted manuscript or as a publisher version. In addition, Laakso (2014) noted the substantial unused potential of green OA on the part of authors.

The current study investigated the OA policies of journals that publish research articles in OA. The SHERPA/RoMEO database (University of Nottingham 2014) was used to obtain information about journal policies, and that information was further crossed-checked by visiting the websites of journals and/or publishers. For OA journals, the information was further double-checked against the Directory of Open Access Journals (DOAJ). For each journal, standard policies on OA publishing (gold $O A$ ) and $O A$ self-archiving policies (green $O A$ ) were examined.

\section{Methodology}

First, we identified the dataset, which involved retrieving research articles on the subject of OA published in LIS journals between 2003 and 2013. The dataset used in this study included articles on OA published in journals indexed in three well-known LIS databases, namely Library and Information Science Abstracts (LISA) (provided by ProQuest), and Library and Information Science Source (LISS) and Library, Information Science and Technology Abstracts (LISTA) (both provided by EBSCO). These well-known indexing and abstracting databases in the field of LIS provide extensive coverage of journals in the field. The same databases were used in previous studies as data sources for evaluating the research output of LIS authors (Click, Wiley \& Houlihan 2017, Fourie, Bitso and Bothma 2014). Vinson and Welsh (2014) argued that LISTA had the broadest range of coverage and is a logical choice for libraries that can only afford a subscription to a single LIS database. Using three databases thus provided comprehensive coverage of the articles, as opposed to relying on a single database which might not offer sufficient accurate coverage and would lead the researchers to draw erroneous conclusions.

An advanced search was conducted in the three databases using 'Open Access' as keyword, while limiting the search to the subject terms field, peer-reviewed articles and English-language publications published between 2003 and 2013. The search was repeated using other OA-related keywords such as 'gold OA', 'green OA', 'institutional repository', 'self-archiving', 'OA journals', 'OA policies' and 'OA mandates'. The retrieved data were organised, duplicates and irrelevant records were removed, and a thorough check was carried out to ensure that the articles in question were relevant to the study and indeed covered the subject of OA. Data for this study were collected in June 2015. The retrieved dataset was saved in the appropriate format using Microsoft Word and plain text, and BibExcel and Excel computer software were used to calculate frequencies and identify which journals published the largest number of research articles on the subject of OA.

Once the dataset had been identified, the second stage involved identifying the OA policies of the journals that published the highest number of articles. Lastly, the OA availability of the set of retrieved articles was determined, then 
checked using Google Scholar and a computer that had no access to library-subscribed materials. Researchers such as Laakso (2014) and Bowley and Vandegrift (2014) used a similar approach.

\section{Framework}

LIS journals with the largest number of articles about OA were subjected to the OA spectrum to determine their level of openness. The OA spectrum - also known as the 'How open is it?' scale - was put forward by the Scholarly Publishing and Academic Resources Coalition (SPARC), the Public Library of Science (PLOS) and the Open Access Scholarly Publishers Association (OASPA) (SPARC 2013). The current study used two of the six components of the OA spectrum, namely reader rights (mostly associated with gold $O A$ ) and author posting rights (mainly associated with green $O A$ ) (see Table 1). These two components were chosen because they are more related to the present undertaking and meet the basic conditions for ensuring the availability of research articles as OA. The other components of the spectrum (copyright, re-use rights, author posting rights and machine readability) were outside the scope of this study. The spectrum was modified to indicate scores which were used to rank the journals based on their level of openness. The ranking was assigned to the gold and green OA provisions respectively, and the two scores were then summed to form an OA score for each journal/publisher.

Table 1 Modified OA spectrum indicating scores

\begin{tabular}{|c|c|c|c|}
\hline $\begin{array}{l}\text { Reader rights } \\
\text { (Gold OA) }\end{array}$ & Score & $\begin{array}{l}\text { Author posting rights } \\
\text { (Green OA) }\end{array}$ & Score \\
\hline Free access to all articles immediately upon publication & 4 & $\begin{array}{l}\text { Authors may archive any version of their work } \\
\text { in any repository or website }\end{array}$ & 4 \\
\hline $\begin{array}{l}\text { Free access to all articles after an embargo period of no } \\
\text { more than six months }\end{array}$ & 3 & $\begin{array}{l}\text { Authors may archive post-print versions in any } \\
\text { repository or website }\end{array}$ & 3 \\
\hline $\begin{array}{l}\text { Free access to all articles after an embargo period of } \\
\text { more than six months }\end{array}$ & 2 & $\begin{array}{l}\text { Authors may archive post-print versions of their } \\
\text { work in certain repositories or websites }\end{array}$ & 2 \\
\hline $\begin{array}{l}\text { Free immediate access to some (but not all) articles, } \\
\text { including hybrid models }\end{array}$ & 1 & $\begin{array}{l}\text { Authors may deposit pre-print versions of their } \\
\text { work in certain repositories or websites }\end{array}$ & 1 \\
\hline $\begin{array}{l}\text { Subscription, membership, pay-per-view or other fees } \\
\text { required to access articles }\end{array}$ & 0 & $\begin{array}{l}\text { Authors may not deposit any version of their } \\
\text { work in repositories or websites }\end{array}$ & 0 \\
\hline
\end{tabular}

Adapted from SPARC (2013)

\section{Scope and limitations of the study}

The study was limited to research articles on the topic of OA, published in LIS journals only. Hence, the source of data was limited to the LIS abstracting and indexing databases (LISS, LISTA AND LISA), and therefore the results cannot be generalised to apply to literature on OA covered by other databases (for example, Web of Knowledge, Scopus, Google Scholar) and indexes. The study does, however, provide comprehensive coverage of the LIS-related sources of research articles on the subject of OA. In analysing journals that publish OA research, the focus was on their 'openness' as opposed to other measures pertaining to the quality of scholarly journals (such as impact factor or $\mathrm{H}$-index).

The study only evaluated the current gold and green policies of leading LIS journals. The status of these policies may have been different at the time the articles were being published, therefore the current green and gold OA policies of the journals evaluated may not necessary have guided authors' decisions on where to submit. It would be virtually impossible to find information on the status of each journal at the time of publication of an analysed article. In addition, journal policies have changed over the years, with most journals only starting to adopt related policies in around 2003. Before this time, it was not common for journals to have explicit rules about posting in institutional repositories. Despite these limitations, the findings of this study provide an indication of the current status of the OA policies to which LIS journals adhere. In addition, the findings offer information which researchers may use when making decisions about where to publish.

\section{Results and discussion}

The total number of scholarly articles on the topic of OA, published in journals indexed in LISS and LISTA databases and available through EBSCOhost was 1,141, and the number published in journals indexed in the LISA database was 254 a total of 1,395 articles. This represents the total number of articles on the subject of OA, published in journals indexed in all three databases (LISS, LISA and LISTA) between 2003 and 2013. After removing all duplicates, the remaining number of articles was 1,185 . These were further analysed to determine their publication sources. 
Table 2 Top 50 journals that published articles on OA

\begin{tabular}{|c|c|c|c|c|c|c|}
\hline & Journal & Publisher & Count & Gold & Green & Total \\
\hline$\overline{1}$ & Learned Publishing & Wiley & 66 & $2_{\# 12 M^{1}}$ & 3 & 5 \\
\hline 2 & Serials Review & Taylor and Francis & 51 & 1 & 2 & 3 \\
\hline 3 & First Monday & University of Illinois at Chicago University Library & 47 & 4 & 4 & 8 \\
\hline 4 & The Serials Librarian & Taylor and Francis & 44 & 1 & 2 & 3 \\
\hline 5 & Information Service and Use & IOS Press & 40 & 1 & 2 & 2 \\
\hline 6 & Serials & Insights: the UKSG journal & 39 & 4 & 4 & 8 \\
\hline 7 & OCLC Systems and Services & Emerald & 36 & 1 & 2 & 3 \\
\hline 8 & Insights: the UKSG journal & Insights: the UKSG journal & 27 & 4 & 4 & 8 \\
\hline 9 & Journal of Academic Librarianship & Elsevier & 26 & 1 & 2 & 3 \\
\hline 10 & Journal of Library Administration & Taylor and Francis & 24 & 1 & 2 & 3 \\
\hline 11 & DESIDOC Journal of Library \& Information Technology & $\begin{array}{l}\text { Defence Scientific Information \& Documentation Centre } \\
\text { (Desidoc) India }\end{array}$ & 22 & 4 & 4 & 8 \\
\hline 12 & $\begin{array}{l}\text { Libre Quarterly: The Journal of European Research } \\
\text { Libraries }\end{array}$ & Association of European Research Libraries & 22 & 4 & 4 & 8 \\
\hline 13 & College \& Research Libraries & Association of College \& Research Libraries & 21 & 4 & 4 & 8 \\
\hline 14 & Library Philosophy \& Practice & University of Idaho Library & 20 & 4 & 4 & 8 \\
\hline 15 & Online Information Review & Emerald & 20 & 1 & 2 & 3 \\
\hline 16 & Journal of the Medical Library Association & Medical Library Association & 19 & 4 & 4 & 8 \\
\hline 17 & $\begin{array}{l}J \text { of the American Society for Information Science \& } \\
\text { Technology }\end{array}$ & Wiley & 19 & 1 & 2 & 3 \\
\hline 18 & Library Hi Tech & Emerald & 17 & 1 & 2 & 3 \\
\hline 19 & Scientometrics & Springer & 16 & 1 & 2 & 3 \\
\hline 20 & Information Research & & 16 & 4 & 4 & 8 \\
\hline 21 & Program: Electronic Library \& Information Systems & Emerald & 15 & 1 & 2 & 3 \\
\hline 22 & IFLA Journal & IFLA & 14 & 1 & 2 & 3 \\
\hline 23 & Science \& Technology Libraries & Taylor and Francis & 13 & 1 & 2 & 3 \\
\hline 24 & Library Review & Emerald & 13 & 1 & 2 & 3 \\
\hline 25 & Journal of Librarianship \& Scholarly Communication & Oregon State University Libraries and Press & 13 & 4 & 4 & 8 \\
\hline 26 & Journal of Scholarly Publishing & University of Toronto press & 13 & 1 & $2 \# 12 \mathrm{M}$ & $3_{\# 12 \mathrm{M}}$ \\
\hline 27 & Inter lending \& Document Supply & Emerald & 12 & 1 & 2 & 3 \\
\hline 28 & SRELS Journal of Information Management & Sarada Ranganathan Endowment for Library Science & 11 & unkn & unkn & \\
\hline 29 & New Review of Information Networking & Taylor and Francis & 10 & 1 & 2 & 3 \\
\hline 30 & Journal of Electronic Resources in Medical Libraries & Taylor and Francis & 10 & 1 & 2 & 3 \\
\hline 31 & Chinese Librarianship & Internet Chinese Librarian Club & 10 & 4 & 4 & 8 \\
\hline 32 & Grey Journal (TGJ) & Grey Literature Community & 10 & unkn & unkn & \\
\hline 33 & Evidence Based Library \& Information Practice & University of Alberta learning Services & 10 & 4 & 4 & 8 \\
\hline 34 & Technical Services Quarterly & Taylor and Francis & 9 & 1 & 2 & 3 \\
\hline 35 & Reference Services Review & Emerald & 9 & 1 & 2 & 3 \\
\hline 36 & Portal: Libraries \& the Academy & Project Muse - The Johns Hopkins University Press & 9 & unkn & unkn & \\
\hline 37 & Journal of Documentation & Emerald & 9 & 1 & 2 & 3 \\
\hline 38 & Information Development & Sage & 9 & 1 & 2 & 3 \\
\hline 39 & Agricultural Information Worldwide & $\mathrm{FAO}$ & 8 & 2\#12M & 4 & 6 \\
\hline 40 & $\begin{array}{l}\text { Libri: International Journal of Libraries \& Information } \\
\text { Services }\end{array}$ & De Gruyter & 7 & 1 & 3\#12M & 4 \\
\hline 41 & Law Library Journal & American Association of Law Libraries & 7 & unkn & unkn & \\
\hline 42 & New Review of Academic Librarianship & Taylor and Francis & 7 & 1 & 2 & 3 \\
\hline 43 & Health Information \& Libraries Journal & Wiley & 7 & 1 & $2 \# 12 \mathrm{M}$ & $3 \# 12 \mathrm{M}$ \\
\hline 44 & Electronic Library & Emerald & 7 & 1 & 2 & 3 \\
\hline 45 & ALISS Quarterly & $\begin{array}{l}\text { Association of Librarians and information professionals } \\
\text { in Social Sciences }\end{array}$ & 7 & unkn & unkn & \\
\hline 46 & American Archivist & Society of American Archivists & 7 & unkn & unkn & \\
\hline 47 & $\begin{array}{l}\text { African Journal of Library, Archives \& Information } \\
\text { Science }\end{array}$ & Archlib and Information Services Ltd & 7 & unkn & unkn & \\
\hline 48 & Cataloging \& Classification Quarterly & Taylor and Francis & 6 & 1 & 2 & 3 \\
\hline 49 & Choice: Current Reviews for Academic Libraries & Association of College and Research Libraries (ACRL) & 6 & unkn & unkn & \\
\hline 50 & Collection Building & Emerald & 6 & 1 & 2 & 3 \\
\hline 51 & European Science Editing & European Association of Science Editors (Ease) & 6 & unkn & $\mathrm{u}$ & \\
\hline 52 & Information Technology and Libraries & Boston College Libraries & 6 & 4 & 4 & 8 \\
\hline 53 & Journal of Electronic Resources Librarianship & Taylor and Francis & 6 & 1 & 1 & 3 \\
\hline 54 & Legal Information Management & Cambridge University Press & 6 & 1 & 2 & 3 \\
\hline 55 & Library Technology Reports & American Library Association & 6 & unkn & unkn & \\
\hline \multirow[t]{2}{*}{56} & $\begin{array}{l}\text { Quarterly Bulletin of the International Association of } \\
\text { Agricultural Information Specialists }\end{array}$ & $\begin{array}{l}\text { Internal Association of Agricultural Information } \\
\text { Specialists }\end{array}$ & 6 & unkn & unkn & \\
\hline & TOTAL & & 909 & & & \\
\hline
\end{tabular}


The 1,185 publications on the subject of OA were published in 379 international peer-reviewed journals. Table 2 shows the fifty-six journals with the most publications, along with their publication counts, which accounted for a total of $909(77 \%)$ articles retrieved from all three databases. The remaining 323 journals had five or fewer articles each, with a third of these journals having published only one article each on the subject. Learned Publishing recorded the highest number of articles in the domain, that is, sixty-six (7.2\%), followed by Serials Review with fifty-one (5.5\%), First Monday with forty-seven (5.1\%), Serials Librarian with forty-four (4.8\%), Information Service and Use with forty (4.4\%), Serials with thirty-nine (4.3\%), OCLC Systems and Services with thirty-six (3.9\%), Insights: the UKSG Journal with twenty-seven (2.9\%) and Journal of Academic Librarianship with twenty-six (2.8\%) articles (see Table 2).

The fifty-six journals identified as having the highest number of publications were analysed based on their level of 'openness' using the 'How open is it?' framework outlined earlier. Table 2 shows the gold, green and total OA scores for each journal. Based on their level of openness and their OA score, journals were divided into five categories, namely OA journals, delayed/embargoed OA journals, hybrid journals with unconditional post-print archiving permissions, hybrid journals with embargoed post-print archiving permissions, and journals with unrecognised OA policies. The description for each category is provided in the section that follows.

\subsection{First category: OA journals}

The first category constitutes journals that attained an OA score of eight (8). All journals in this category were OA. Of the fifty-six journals that had more publications, thirteen (22\%) attained the highest score of eight, that is, a gold OA score of four (4) and green OA score of four (4) (see Table 2). These journals provide free access to all articles immediately upon publication and allow authors to archive any version of their work in repositories, on personal websites or on any other location on the internet.

The OA journals, which published a total of $272(29.7 \%)$ articles, include First Monday (forty-seven articles), Serials (thirty-nine), Insights: the UKSG Journal (twenty-seven), Desidoc Journal of Library \& Information Technology (twentytwo), Libre Quarterly (twenty-two), College \& Research Libraries (twenty-one), Library Philosophy \& Practice (twenty), Journal of the Medical Library Association (nineteen), Information Research (sixteen), Journal of Librarianship \& Scholarly Communication (thirteen), Chinese Librarianship (ten), Evidence-Based Library \& Information Practice (ten) and Information Technology and Libraries (six). Serials Journal changed its name in 2012 to Insights: the United Kingdom Serial Group (UKSG) Journal. All the back files of Serials Journal (volumes 1-24) have been digitised and are available online as OA (UKSG 2015).

All thirteen OA journals identified in this category were published by either societies, libraries or university presses, and did not charge authors article processing costs (APCs). In terms of green OA, all journals in this category allowed self-archiving without restrictions, meaning authors were allowed to deposit the final version of their publication in institutional repositories or on any other location on the web, without paying a fee or being subject to an embargo. As expected, all articles published in these OA journals were also available as OA.

\subsection{Second category: delayed/embargoed OA journals}

The second category included journals that attained an OA score of between four (4) and six (6). All journals in this category were delayed/embargoed. Three journals (5.3\%) fall under this category: Learned Publishing (sixty-six articles) and Agricultural Information Worldwide (eight articles) are delayed OA journals which provide free access to all articles after an embargo period of one year (in terms of green OA, Learned Publishing allows authors to archive post-print versions of their articles in a wide range of locations, including the authors' own websites or their institutional websites, as well as pre-prints in relevant subject areas on free public servers; Agricultural Information Worldwide permits authors to archive any version of their publications on personal websites or repositories).

The third journal in this category is Libri (seven articles), a toll access journal that allows authors to self-archive the publisher's version after an embargo period of twelve months. All journals in this category ensure OA to the final version of the published work, either automatically after an embargo period (for example, through delayed OA) or through author self-archiving. These publications featured a total of eighty-one articles $-8.8 \%$ of all articles appearing in the fifty-six journals. Some journals on this list, such as Learned Publishing and Libri also featured in Xia's (2012) study, where they were categorised as LIS journals with conditional OA.

All articles appearing in the three delayed/embargoed OA journals were also available as OA: seventy-four (91\%) of the articles published in these journals were available as gold OA, while seven (9\%) were available as green OA.

\subsection{Third category: hybrid journals with unconditional post-print archiving permissions}

The third category includes journals with an OA score of three (3). Twenty-seven (49\%) journals fall under this category and published a total of $404(41 \%)$ of all articles across the fifty-six journals. In terms of gold OA, all publications in this 
category were toll access journals with a hybrid model of OA (a model which applies where a predominantly subscriptionbased journal offers authors the option to make their articles freely available online upon publication, in return for paying an APC). The hybrid model of OA is also known as the author choice model, optional OA or open select programme (Björk 2012).

In terms of green OA, journals in this category did not allow the archiving of the publisher's version. Instead, authors were allowed to self-archive post-print versions of their work immediately after publication, without any other restriction. Certain journals in this category were, however, very specific about the location of the green copies. For most, the permitted locations included personal websites and institutional repositories. In a few cases, funders' and sponsors' websites or repositories were also allowed. Most of these journals excluded other locations (for example, subject repositories, the repositories of other institutions or those of profit-based organisations). Some journals only allowed selfarchiving if the authors' institution had an OA policy or mandate that required them to self-archive. Other conditions given include providing a link to the published article on the website of the publisher and inserting a citation of the published article.

The conditions associated with the right to self-archive - particularly the permitted location of green copies - have serious implications for authors, especially those from developing countries. In most cases, the latter are unlikely to have their own personal websites, and/or their institutions might not have established institutional repositories or mandated self-archiving, thus further reducing the percentage of articles that can be made available via this model. Despite these shortcomings, however, it was possible to access the research articles published as OA, if the researchers exercised their right to self-archive. Journals in this category include: Serials Review (fifty-one articles), Serials Librarian (forty-four), Information Services \& Use (forty), OCLC Systems and Services (thirty-six), Journal of Academic Librarianship (twentysix), Journal of Library Administration (twenty-four), Online Information Review (twenty), Journal of the American Society for Information Science \& Technology (nineteen), Library Hi Tech (seventeen), Scientometrics (sixteen), Program: Electronic Library \& Information Systems (fifteen), IFLA Journal (fourteen), Science \& Technology Libraries (thirteen), Library Review (thirteen), Interlending \& Document Supply (twelve), New Review of Information Networking (ten), Journal of Electronic Resources in Medical Libraries (ten), Technical Services Quarterly (nine), Reference Services Review (nine), Journal of Documentation (nine), Information Development (nine), New Review of Academic Librarianship (seven), Electronic Library (seven), Cataloging \& Classification Quarterly (six), Collection Building (six), Legal Information Management (six) and Journal of Electronic Resources Librarianship (six).

As seen in Table 2, journals in this category are owned by publishing companies such as Taylor and Francis, Emerald, Sage, and Springer. Table 3 shows that about half $(240 ; 53 \%)$ of the papers published in hybrid journals were available as OA. Of these, seventy-one $(30 \%)$ were available as gold copies, meaning that the authors had paid fees to make those texts available as OA. The 169 articles available as green copies constituted $70 \%$ of the articles published in these journals, meaning that authors took the initiative to self-archive the texts in institutional repositories.

\subsection{Fourth category: hybrid journals with conditional post-print archiving permissions}

The fourth category included journals which had attained an OA score of three, but had conditions attached to their postprint archiving permissions. Health Information \& Libraries (seven articles) and Journal of Scholarly Publishing (thirteen) fall in this category (see Table 2). These journals had a total publication count of twenty articles.

In terms of gold OA, the two journals followed a hybrid model, while for green OA, they only allowed self-archiving of the pre-print versions of the articles immediately post-publication, and of the post-print version only after an embargo period of 12-24 months. The permitted self-archiving locations for these two journals include the authors' personal websites, the authors' company/institutional repositories/archives, and not-for-profit subject-based repositories such as PubMed Central. Six (30\%) of the articles published in hybrid journals with embargoed post-print archiving permissions were available as $\mathrm{OA}$.

\subsection{Journals with unrecognised OA policies}

Although all journals in this category were toll access, it was impossible to access their green OA policies, as the information was either unclear or had not been provided. These journals did not explicitly set out their green OA policies on their websites, nor was policy-related information available on the SHERPA/RoMEO website.

As shown in Table 2, eleven journals (19\%) belonged in this category, and had a joint publication count of $112(12 \%)$. These included SRELS Journal of Information Management (eleven articles), Grey Journal (ten), Portal: Libraries \& the Academy (nine), ALISS Quarterly (seven), Law Library Journal (seven), African Journal of Library, Archives \& Information Science (seven), American Archivist (seven), Library Technology Reports (six), Choice: Current Reviews for Academic Libraries (six), European Science Editing (six) and Quarterly Bulletin of the International Association of Agricultural Information Specialists (six). The implication is that it would be difficult for authors publishing in these journals to exercise 
their self-archiving rights, because information on what is permitted, is not available. However, an analysis of the OA availability of articles published in these journals indicated that $35.7 \%$ of the articles were available as OA.

Table 3 OA status of published articles

\begin{tabular}{|c|c|c|c|c|c|c|c|}
\hline Journals & $\begin{array}{l}\text { Number of } \\
\text { journals }\end{array}$ & $\begin{array}{l}\text { Total no. of } \\
\text { articles }\end{array}$ & Gold copies & $\begin{array}{l}\text { Green } \\
\text { copies }\end{array}$ & $\begin{array}{l}\text { Closed } \\
\text { articles }\end{array}$ & $\begin{array}{l}\text { Total no. of } \\
\text { OA articles }\end{array}$ & $\begin{array}{c}\text { OA articles } \\
(\%)\end{array}$ \\
\hline OA journals & 13 & 272 & 272 & $\mathrm{~N} / \mathrm{A}$ & 0 & 272 & 100 \\
\hline Delayed OA & 3 & 81 & 74 & 7 & 0 & 81 & 100 \\
\hline Hybrid/unconditional post-print & 27 & 454 & 71 & 143 & 240 & 214 & 53 \\
\hline Hybrid/conditional post-print & 2 & 20 & 0 & 6 & 14 & 6 & 30 \\
\hline Unrecognised & 11 & 82 & 14 & 15 & 53 & 29 & 35.7 \\
\hline TOTAL & 56 & 909 & 431 & 171 & 307 & 602 & 66 \\
\hline
\end{tabular}

\subsection{Open access availability of the articles}

The results of this study show that the majority of the articles, that is 404 (44.1\%) (see Table 2), were published in hybrid journals with green OA policies that allow the self-archiving of the post-print version of a publication. The articles were published in twenty-eight (49\%) journals. The OA policies of these journals place the responsibility for ensuring OA solely in the hands of the authors, either through payment of the APC (to make their articles OA, that is, the hybrid model) or through self-archiving of post-print versions of their texts, which means the articles will only be available as OA if the authors take the initiative to self-archive or pay the article processing cost.

Studies on the self-archiving levels of LIS researchers indicate that such archiving is not a regular practice in the field and that articles are not being deposited in institutional or subject repositories at a high rate (Björk 2012, Bowley and Vandegrift 2014, Mercer 2011). Way (2010) reported that only $27 \%$ of articles in that study were found to have selfarchived green versions. By contrast, the findings of the current study indicate that $171(19 \%)$ of publications were available as OA due to self-archiving initiatives on the part of the authors (see Table 3). This indicates that self-archiving is not a regular practice even for LIS researchers who deal with the subject of OA and who are presumably more aware of what the self-archiving process entails. A study by Björk (2012) further reported that, on average, only $1 \%$ to $2 \%$ of eligible authors utilise the hybrid option due to high costs - typically US $\$ 3,000$. In this study, as seen in Table 3, seventyone $(15 \%)$ of the articles published in hybrid journals were available as gold copies due to either the payment of APCs by authors or another arrangement by journals to make the articles OA.

In summary, the findings show that of the 906 articles which LIS scholars published on the subject of OA, some $29 \%$ appeared in OA journals, with an additional $8 \%$ appearing as delayed OA, making a total of $37 \%$ of articles available through gold OA. These results are slightly higher than the findings reported in previous studies. For instance, Laakso and Björk (2012) established that some 11\% of the 1,658,643 articles published in 2011 in Scopus were full OA, with an additional $5.9 \%$ appearing as hybrid or delayed OA, to total $16.9 \%$. For Web of Knowledge, only $9 \%$ of the 1,294,051 articles published in 2011 were full OA, while $7.2 \%$ were hybrid or delayed OA, making a total of $16.2 \%$. This indicates that, in general, the adoption and growth of $O A$ for research articles on the subject of $O A$ is somewhat higher than in other fields.

As is the case in other disciplines, LIS researchers face the question of where best to submit their manuscripts if they want to make a meaningful contribution to their domain. The dilemma of where to publish is further complicated by the requirement that authors publish in major or core journals in their field as well as ensure that their research outputs are available as OA by either exercising their right to self-archive or making use of the various OA provisions and policies adopted by the journals. The expectation that authors should ensure the OA availability of their research articles is much higher for LIS professionals who have been at the forefront of OA advocacy and who are expected to lead by example.

\section{Conclusions and recommendations}

This study sought to investigate the degree to which journals' OA policies facilitate free access to publications, in addition to determining whether such publications are also available as $O A$. The results show that literature growth in the domain has been significant over the last eleven years, with a total of 1,402 articles produced during that period. The OA policies of fifty-six journals were analysed, and it was found that most articles were published in hybrid journals with green OA policies which allowed authors to archive post-print versions of their texts. Some twenty-eight (49\%) of the journals reviewed followed the hybrid model.

Only $272(29.7 \%)$ of the articles were published in OA journals (first category), which constituted thirteen (22\%) of the journals reviewed, while only three $(5.3 \%)$ of the journals used the delayed OA model (second category), with a total 
publication count of eighty-one (8.8\%) - the two categories comprised a total of sixteen journals. Further analysis of the journals in these categories showed that six (37\%) were indexed in the Scopus database during 2018, including College and Research Libraries, Information Research, Evidence Based Library \& Information Practice, Information Technology and Libraries, Learned Publishing and Libri. These journals may be of interest to South African authors who wish to publish in OA/delayed OA journals which are accredited and therefore qualify for subsidies from the Department of Higher Education and Training.

The findings of this study serve to raise awareness of the available body of literature on the subject of OA and the LIS journals in which most research on OA is published. An analysis of the LIS journals that publish the bulk of OA-related articles creates core reading sources for scholars researching the subject. Journals that publish articles in OA are likely to receive more attention from researchers focusing on this topic. A study by Miguel, Tannuri de Oliveira and Cabrini Grácio (2016) reported that OA scholars were concerned about sharing the new knowledge generated on this theme in journals whose publication policy allows $O A$ access to articles either via the green or gold route. Although it cannot be assumed that LIS scholars doing research on OA are in favour of OA, studies report that the most prolific and most-cited authors in the domain are also defenders, activists and advocates of $O A$ who are concerned about making their research publications openly accessible (Miguel, Tannuri de Oliveira and Cabrini Grácio 2016). This shows that there is some level of interest in making publications $O A$ among scholars researching the topic. There is also a general expectation that research on this specific theme should be available in OA.

The information on the OA policies of journals publishing OA research may assist authors and researchers in deciding which journals are appropriate for manuscript submissions. The study calls on LIS professionals - especially those doing research on OA - to be conversant with the OA-related policies of those journals that publish their work. LIS professionals are often accused of not exercising their self-archiving rights (Mercer 2011), partly because they are unaware of the green access policies of the journals to which they submit.

In view of the foregoing results, further investigation is needed to analyse articles about $O A$, which are not available in this format. Such a study should shed light on whether scholars researching OA are also in favour of the unrestricted access. In addition, such a study will ascertain whether scholars researching OA have fully embraced the notion. Further research is needed into the OA articles appearing in LIS journals indexed by Web of Knowledge and Scopus, as such an analysis would enable South African authors to make a practical choice where subsidies come into play.

\section{References}

American Psychological Society (APS). 2007. Opening up open access: weaving the 'author pays' safety net. The Physiologist, 50(30): 106-107.

Björk, B.C. 2012. The hybrid model for publication of scholarly articles: a failed experiment? Journal of American Society of Information Science, 63(8): 1496-1504.

Bowley, C. and Vandegrift, M. 2014. Librarian heal thyself: a scholarly communication analysis of LIS journals. In the Library with the Lead Pipe. 23 April. DOI:10.6084/m9.figshare.994261.

Click, A.B., Wiley, C.W. and Houlihan, M., 2017. The internationalization of the academic library: a systematic review of 25 years of literature on international students. College \& Research Libraries, 78(3): 328-358.

Fourie, I., Bitso, C. and JD Bothma, T., 2014. Methods and resources to monitor internet censorship. Library Hi Tech, 32(4): 723-739.

Laakso, M. 2014. Green open access policies of scholarly journal publishers: a study of what, when, and where selfarchiving is allowed. Scientometrics, 9(2): 475-494.

Laakso, M. and Björk, B.C. 2012. Anatomy of open access publishing: a study of longitudinal development and internal structure. BMC Medicine, 10(124): 1-9

Lin, S. 2006. Delayed open access or permanent non-open access. Molecules, 11(7): 496-497.

Mercer, H. 2011. Almost halfway there: an analysis of the open access behaviors of academic librarians. College \& Research Libraries, 72(5): 443-453.

Miguel, S., Tannuri de Oliveira, E.F. and Cabrini Grácio, M.C. 2016. Scientific production on open access: a worldwide bibliometric analysis in the academic and scientific context. Publications, 4(1): 1-16

Mizera, K. 2013. Delayed vs. immediate open access. [Online]. http://openscience.com/delayed-vs-immediate-openaccess/ (11 December 2014).

Poynder, R. 2012. Open access mandates: ensuring compliance. [Online]. http://poynder.blogspot.com/2012/05/openaccess-mandates-ensuring.html (15 December 2014).

Registry of Open Access Repositories Mandatory Archiving Policies (ROARMAP). 2014. Registry of Open Access Repositories Mandatory Archiving Policies. [Online]. http://roarmap.eprints.org/ (7 April 2014).

Scholarly Publishing and Academic Resources Coalition (SPARC). 2013. How open is it? The open access spectrum. [Online]. http://sparc.arl.org/sites/default/files/hoii_guide_rev4_web.pdf (8 September 2014).

Tonta, Y., Doğan, G., Al, U. and Madran, O. 2015. Open access policies of research funders: the case study of the Austrian Science Fund (FWF). [Online]. 
https://www.fwf.ac.at/fileadmin/files/Dokumente/Ueber_den_FWF/Publikationen/FWF-Selbstevaluation/FWF-OAPolicy-Case-Study_Pasteur4OA.pdf (7 April 2014).

United Kingdom Serial Group (UKSG). 2015. Serials: The Journal for the Serials Community [Online]. http://uksg.metapress.com/content/107730/?genre=journal\&issn=0953-0460 (8 January 2015).

University of Nottingham. 2014. Publisher copyright policies and self-archiving. [Online]. http://www.sherpa.ac.uk/romeo/ (8 May 2014).

Way, D. 2010. The open access availability of library and information science literature. College \& Research Libraries, 71(4): 302-309.

Vinson, T.C. and Welsh, T.S. 2014. A comparison of three Library and Information Science Databases. Journal of Electronic Resources Librarianship, 26(2): 114-126.

Xia, J. 2012. Positioning open access journals in a LIS journal ranking. College \& Research Libraries, 73(2): 134-145.

Xia, J., Wilhoite, S.K. and Myers, R.L. 2011. A "librarian-LIS faculty" divide in open access practice. Journal of Documentation, 67(5): 791-805. 